devoted to the energy aspects of the forest industries. At one it was indicated that the energy input of the industry itself to pulp and paper manufacture ranged from $5-35 \%$ in different countries, with a very much lower figure ( $5 \%$ only) for the input to the mechanical processing side. Sweden, again, is a leader in examining how these figures could be improved by more efficient use of forest waste: one recent estimate gives 50 million $\mathrm{m}^{3}$ of residues consumable as fuel if not partially recovered for other processing, for every 60 million $\mathrm{m}^{3}$ of commercial round wood produced annually.

Again, in Finland it is estimated that small sized wood, stump/root systems and other forest waste could provide 3.6 million tons oil equivalent a year, with another 0.8 mtoe depending on the market for certain hardwood products. Timber industries, faced with rapidly rising energy costs from conventional sources, are examining new ways of using their own waste products, either by direct combustion or through conversion into gas or liquid fuels. An advantage is that wood is not carcinogenic and is low in both nitrogen and sulphur. According to one ECE reort, forest product industries can and should become energy independent soon, later supplying surplus biomass to other users.

Peter Collins

\title{
Poland calls for wider research cooperation . . .
}

International cooperation at every level from pure academic research to industrial design and implementation - is essential if a country's research potential is to develop to its full capacity. So Jan Mazurkiewicz, Director of 'Export and Economic Relations with Abroad' of the Polish Ministry of the Machine Industry told Nature recently. He was summarising the significance of "Poland's Technology, 1979"' a series of seminars and technical exhibitions held last week in London, Manchester, Birmingham, and Coventry.

The close integration of research with industry is a basic feature of Polish planning. It was perhaps less familiar to some of the British participants, who seemed a little at a loss as to whether to expect learned discourses or sales promotion talks. For the event, sponsored on the British side by the Chambers of Commerce of the host cities, was the reciprocal or a similar British week in Warsaw last autumn, and represents one of the more positive results of Poland's large trade gap with Britain.

If trade between the two countries is to increase - and the state of the Polish economy makes this highly desirable some new form of cooperation must be found. Recently, joint research and development projects, culminating in joint production for a third market, has increasingly been proposed on both sides as an attractive solution.

Any viable proposal for joint projects presupposes, that both sides know what the other has to offer. "A symposium means the meeting of people with like interests", Mr Mazurkiewicz explained. "So we chose our team very carefully - a couple of academicians, a test pilot, two plant engineers, an administrator, and so on. We looked for a good variety, for people with open minds, with whom there could be a point of contact."

The subjects, which ranged from medical electronics to machine tools and from computer software to agricultural aviation, were selected by the Polish side as fields where they felt they had something valuable to offer. Inevitably, in the discussion of any cooperation projects, sooner or later the problem of strategic military embargoes crept in. These, however, were peripheral, and in one instance, Jacek Szporko of "Unitra-
Elektron" joked that the strategic embargo of the early 1960s had indirectly led to Poland's present expertise in semiconductor technology.

The close links between Polish research and industry meant that the Polish team could include lecturers of considerable international standing. Andrzej Radziminski (software and computer services) is a member of the Advisory Committee for Informatics Projects of the International Bureau for Informatics Dr Tadeusz Zak, who lectured on the Polish technological equipment industry, is a member of the Comecon Plenipotentiary Committee for Corrosion Problems, and Dr Halina Leszcynska (industrial sulphur processing) was closely involved in the development of granulated sulphur. This is free of the health and environmental hazards that had been closing more and more ports throughout the world to sulphur in its traditional powder form.

Dr Leszczynska is a member of the Committee of Chemical Sciences of the Polish Academy of Sciences, and, as such, represented a field which, she said, is always in the "top three places of research investment", due to its "importance in the

\section{. . . while the East Germans must wait for a trade agreement first}

THE German Democratic Republic, which celebrated its 30 th anniversary recently, is a country where, according to Dr Lutz Buschendorf, First Secretary (Science and Technology) of the GDR Embassy in London, every single worker is to some extent involved in science. Unfortunately, he said, so far scientific cooperation between the UK and the GDR has not developed to the extent one might have hoped. The reason, from the East German point of view, is the "unwillingness" of the UK to sign a cooperation agreement in which science and technology would not be linked to trade.

At present, technological cooperation comes under the Joint Agreement, originally drawn up in 1973 , in which the British side comes under the aegis of the Department of Trade. This is the standard situation for all UK cooperation deals with Eastern Europe. The involvement with trade has a two-fold basis. Firstly, from the national economy". She was particularly optimistic about the outcome of the week. "There are already a lot of people doing joint research at post-graduate level", she said. "What this week has done is to provide new direct contacts at the development level."

Several members of the Polish team, in informal discussions, suggested that joint industrial and development projects should ideally be based on truly joint research, rather than bringing together the results of research at a late stage.

Although the symposium, was slanted rather towards the industrial end of the research and development strectrum, the lectures from time to time revealed interesting sidelights on Polish research structure which would undoubtedly have to be taken into account in the planning of any joint research. Who would have guessed - until test pilot Wieslaw Mercik pointed it out - that the Warsaw Aviation Institute does no work at all on whole-body helicopter design, but is simply responsible for testing the aerodynamic and performance characteristics of designs produced in the factory design offices?

Vera Rich

beginning, the UK felt that if the agreements were to bring genuinely mutual benefits, then some kind of counter-trade would be needed to off-set a predominantly one way, West to East flow of technology. Secondly, the administration of the agreements by the Department of Trade (via a special technology unit) is a result of the way the ministry of technology was dismantled.

To the East Germans, however, the link with trade constitutes a major psychological block. When the then UK Secretary of State for Trade, Edmund Dell, visited the GDR some three years ago, he stressed that under existing economic conditions the trade turn-over between the UK and the GDR could well be doubled. Some Germans seem to have taken this as a direct challenge to their thesis that increased scientific and technological cooperation should pre-date any major expansion of trade. "We want to make 